\title{
ENVIRONMENTAL QUALIFICATION OF ASH FROM WOOD-BASED RECYCLED FUELS FOR UTILIZATION IN COVERS FOR LANDFILLS
}

\author{
Rolf Sjöblom ${ }^{l}$ \\ Gustav Tham ${ }^{2}$ \\ Jan-Erik Haglund \\ Cecilia Sjö̈̈ ${ }^{3}$ \\ ${ }^{\prime}$ Tekedo $A B$ \\ ${ }^{2}$ Telge $A B$ \\ ${ }^{3}$ Söderenergi $A B$
}

\begin{abstract}
Combustion of recycled fuels as well as incineration of waste are excellent means to generate heat and to convert redundant objects and spent items to a form that readily lends itself to sampling and characterization. Many harmful substances may be efficiently destroyed in the process and others, such as heavy metals, may become concentrated.

Consequently, it is necessary that any decision on the future fate of an ash volume be based on the content (as checked by chemical analysis) as well as on the availability (as checked by leach tests) of possibly hazardous substances. However, in the case of heavy metals in ash, an assessment based on content - and by direct application of the existing legislation - is essentially impossible to carry out in practice. The reason is that the chemical form is very complex and cannot readily be associated with the substances appearing in the data bases on hazardousness of chemical substances. Another major concern is that the assessments need be valid for very long times while the time spans available for measurements and experiments is very short in comparison.
\end{abstract}

A methodology to cope with these issues has been developed and applied in a project on utilization of ash in covers, including seals, for landfills. At present, four hectares of old domestic waste have been protected at Telge Återvinning AB (Telge Recycling Plant) in a full scale test and the plans for the subsequent step include another eleven hectares. The ash originates from recycled wood based fuel (also containing paper and plastics) combusted for district heating purposes at Söderenergi AB (Igelstaverket).

It was found that it is possible to identify reference substances which appear in the data bases on hazardousness and which represent the actual chemical form of the various elements in a conservative manner. In order for such an approach to be valid and robust, it was found necessary that a knowledge base on chemical composition and speciation be developed and compiled.

The knowledge base is also used for predictions of the future properties and behaviour of the ash in terms of content and availability of hazardous substances as well as and permeability. 
The Swedish legislation is the prerequisites for the work together with the National strategy of the thousand year perspective as expressed by the Swedish Environmental Protection Agency. Our legislation is based on that of the European Union and is thus very similar in a number of countries.

\section{KEYWORDS}

Ash; Wood; Waste; Recycle; Fuel; Seal; Cover; Landfill; Hazardous; Conservation

\section{INTRODUCTION}

The Ordinance of waste [1] issued by the Swedish Govemment regulates how waste must be managed. The Ordinance harmonizes with European Union Council Directive 91/689/EEC of 12 December 1991 on hazardous waste. According to the Ordinance, the management of waste is largely dictated by its classification, i e whether the waste is hazardous or not.

Moreover, classification of a waste as non-hazardous implies that it may be deposited in a landfill for non-hazardous waste without testing, see further below.

Historically, differentiation between hazardous and non-hazardous waste has been made using the European Waste Catalogue (EWC). It is still in force as a basis for classification but has for many of the entities been provided with so-called mirror entries. This means that one type of waste is divided in two categories, one of which comprises waste containing dangerous substances and the other one comprises other wastee.

A dangerous substance has at least one of the following properties: explosive, oxidizing, flammable, very toxic, toxic, harmful, corrosive, irritant, carcinogenic, toxic for reproduction, mutagenic and toxic to the environment. Also, substances that might give rise to some other substance that has dangerous properties are included. Limits are given for each of these properties, either as a maximum value for each substance, or as a total concentration of the substances that have the property in question. No limit is given for toxic to the environment, however ${ }^{2}$.

The Ordinance on deposition, criteria and procedures for the acceptance of waste at landfills [2] issued by the Swedish Environmental Protection Agency $^{3}$ regulates what waste can be accepted at the different types of landfills: for inert waste, for non-hazardous waste and for hazardous waste. ${ }^{4}$

In many cases, acceptance for ash at a landfill might be earned through leach tests provided that the concentrations in the leachates are below certain statutory levels. It is also stipulated, at least for most cases, that the ability to contain dangerous substances must not deteriorate over time.

\footnotetext{
I Actually waste containing dangerous substances below certain threshold levels.

${ }^{2}$ Toxic to the environment and the property to give rise to some other substance are not mentioned in the European Union Council Directive 91/689/EEC of 12 December 1991 on hazardous waste. They appear in the Hazardous waste directive (HWD, Council Directive 91/689/EC), however.

3 In accordance with a general delegation from the Government.

${ }^{4}$ Note that classification of waste is done according to the Ordinance of waste[1] and into the categories hazardous and non-hazardous. Application of the acceptance criteria does not result in any classification, only that certain waste may be deposited in some particular class of landfill.
} 
It was mentioned above that waste classified as non-hazardous may be deposited in a landfill for non-hazardous waste without testing. In such a case, hazardous waste that meets the criteria for disposal at a landfill for non-hazardous waste must not be deposited in the same cell.

There is a rationale for what might appear to be a duplication of rules. The Ordinance of waste sets limits to the potential for disturbance of health and environment while the acceptance criteria limits the availability. In the case of non-hazardous waste and a landfill for non-hazardous waste, the potential is limited. Moreover, since the landfill is designed for nonhazardous but not necessarily inert waste, it provides a certain protection against releases. Consequently, it is not necessary to determine the availability.

When a certain waste is to be characterized for potential utilization, it is pertinent to first check whether it is hazardous or not. If it is hazardous, the appropriate destination in most cases is deposition. Special reasons will have to be found in order for other fates to be warranted. One such example is a high content of calcium hydroxide in which case the ash is irritant or even corrosive. However, the high lime value may well make the ash very attractive as an additive in concrete, and the hazardous properties can be predicted with certainty to disappear as soon as the product has cured.

At present, the regulations on how ash material is to be qualified from a health and environmental point of view and for geotechnical purposes at a landfill leave much to interpretation. In many cases, utilization is based on a court ruling on an application containing an environmental impact statement. This implies that any effects on health and environment have been shown to be small or at least acceptable. Nonetheless, comparison is frequently made with other regulations. Rules can actually only be applied for the purposes for which they are intended. However, it is frequently a good idea to make comparisons in order to ensure that nothing essential might have escaped attention.

Thus, the leach tests intended for determining acceptance at landfills can be useful also in evaluations of what might become mobile in geotechnical constructions in which recycled material is utilized.

Sometimes comparison is also made with the recommendations of the Swedish Environmental Protection Agency on contaminated soils. Such approaches may be very treacherous, however, since the properties of ordinary soil material and ash are usually very different, and sometimes the availability differs by orders of magnitude [3].

Direct application of the Ordinance of waste to incineration and combustion residues is impossible for practical purposes. The reason for this is that the chemical forms of the various elements are very complex involving many phases and variable compositions. For the most part, these forms do not appear in the data bases which exist for hazardous substances.

Consequently, it might appear tempting to conclude that since the actual substances are not covered in the data bases in question, no classification as hazardous waste is required. Such an approach would, however, contradict the intent of the legislation and has therefore been rejected. 
Instead, reference substances have been identified which do appear in the data bases for hazardous substances and which are conservative but not unreasonable representations of the actual ones and the basic methodology is presented in Reference [4].

It should be mentioned in the present context that it is imperative that classification according to the Ordinance of waste[1] actually be carried out. As in other countries our environmental legislation requires that health and environment be protected and that recycling and conservation be practiced at the same time. Consequently, it is illegal to avoid an appropriate classification of residues by simply referring to the principle of caution since this might lead to waste of useful material as well as unwarranted occupation of qualified landfill space needed for the intended purposes.

\section{THE INTENDED USE FOR THE ASHES}

Telge Återvinning AB (Telge Recycling Plant) possesses a total of 2,5 million cubic meters of domestic waste which has accumulated throughout the years. It extends over a large area of which 35 hectares is planned to be covered within the next $5-10$ years.

Initially, Telge Recycling Plant investigated commercially available materials for the covers [1] (Brundin et al 2001) but soon found that they may be sensitive to various influences and difficult to qualify for long times. Instead, the following approach has been taken and applied:

- Utilization of recycled materials, especially ash from recycled wood-based fuels

- The cover should have suitable mechanical properties with regard to differential settlements in the waste as well as slope stability

- The cover should have suitable chemical properties to resist undesired influences from other materials as well as to undergo continuous improvement in properties

- The results and conclusions should have a sound and solid scientific and technical basis, including results from tests on a sufficiently large scale

Telge Recycling Plant has recourse to considerable volumes of incoming wood based ash as well as a stockpile of its own (ca 600000 tonnes), for the very most part originating from the district heating operations at Igelstaverket owned and operated by Söderenergi AB.

The basic outline of a cover showing the sequence of layers is presented in Figure 1. At present, an area of four hectares has been covered for test and demonstration purposes. The subsequent step is to cover an area of eleven hectares.

The design and construction of covers for seals over old domestic waste is strongly interlinked with the properties of the materials intended to be used. Thus materials will have to be characterized, the design accommodated, functional requirements established and the materials qualified. The functional requirements include the following:

- Imperviousness to water

- Mechanical strength

- Ability to deform plastically
- Shear stability

- Meet high standards on health and environment

- Develop well over time 


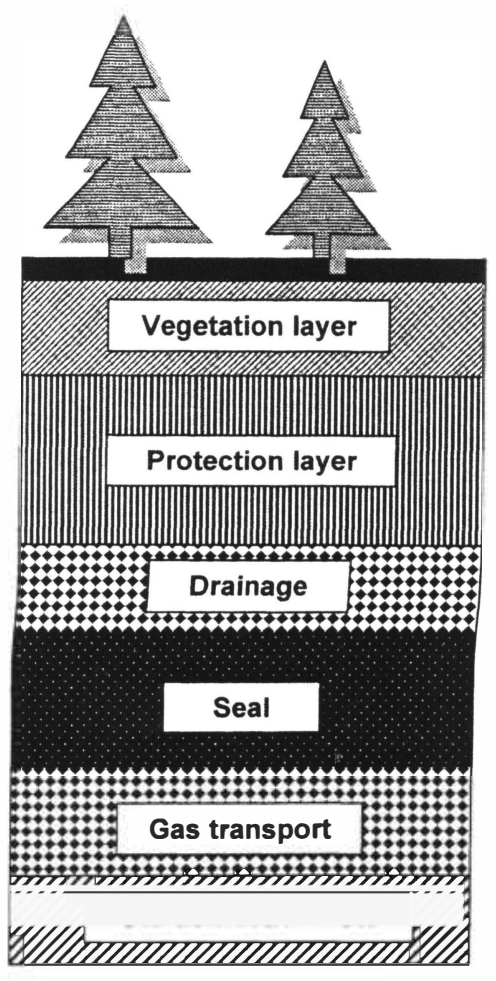

Figure 1. (Left) The basic outline of the covers showing the sequence of layers. The seals are typically made of ash, with and without addition of bentonite clay and LD-slag. The protection layer typically consists of a mixture of ash and digested sludge.

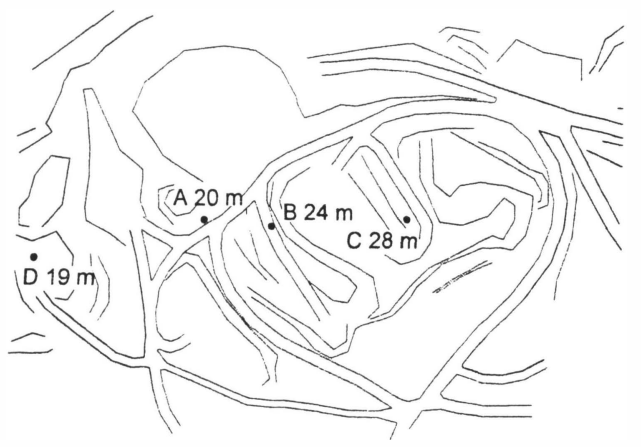

Figure 2. (Above) Positions of the drill holes together with their total depths. The holes penetrate to below the ash. The largest horizontal distance between the holes is 168 meters.

\section{CHARACTERIZATION OF THE ASH}

Sampling from the ash store was carried out using mainly percussion drilling with ODEX technique. The positions of the drill holes are given in Figure 2. The drill rod (actually a pipe) is inside a casing and both are hammered down simultaneously. When in operation, the drill head expands to a diameter larger than the casing. The hammer is driven by compressed air which also transfers the debris formed to the surface. Intermittently, auger technique (with a helix-shaped screw drill) was used to check that the compressed air did not dry the material and cause error in the moisture content determinations. The material was collected in a drum using a cyclone. Two composite samples were taken for every meter, one of which was subsequently crushed and homogenized.

The ash samples were characterized with regard to a large number of properties including water content, $\mathrm{pH}$ of pore water, content of ions in pore water, chemical composition (major and minor elements in solid matter and leachate) and heat absorption and weight loss versus temperature. Only examples of data relevant for the environmental qualification are given here. The chemical compositions of some of the samples from drill hole A (cf Figure 2) are given in Table 1 for certain minor elements in the solid phase and in Table 2 for certain elements in leach water. 
Table 1. Minor elements in ash at the store at the Tveta Recycling Plant in $\mathrm{mg} / \mathrm{kg}$ (ppm by weight) figured as elements. Samples taken from drill hole A (cf Figure 2).

\begin{tabular}{cccccccccc}
\hline $\begin{array}{c}\text { Ele- } \\
\text { ment }\end{array}$ & $0-1 \mathrm{~m}$ & $2-3 \mathrm{~m}$ & $4-5 \mathrm{~m}$ & $6-7 \mathrm{~m}$ & $8-9 \mathrm{~m}$ & $\begin{array}{c}11-12 \\
\mathrm{~m}\end{array}$ & $\begin{array}{c}13-14 \\
\mathrm{~m}\end{array}$ & $\begin{array}{c}15-16 \\
\mathrm{~m}\end{array}$ & $\begin{array}{c}16-17 \\
\mathrm{~m}\end{array}$ \\
\hline $\mathrm{Sb}$ & 7 & 7 & 8 & 5 & 3 & 5 & 6 & 6 & 6 \\
$\mathrm{As}$ & 28 & 30 & 28 & 22 & 10 & 13 & 13 & 19 & 19 \\
$\mathrm{~Pb}$ & 99 & 119 & 97 & 72 & 47 & 81 & 95 & 105 & 105 \\
$\mathrm{Co}$ & 38 & 41 & 42 & 32 & 25 & 32 & 31 & 33 & 33 \\
$\mathrm{Cu}$ & 114 & 110 & 130 & 95 & 80 & 100 & 91 & 71 & 71 \\
$\mathrm{Cr}$ & 132 & 150 & 134 & 126 & 112 & 115 & 116 & 80 & 80 \\
$\mathrm{La}$ & 36 & 56 & 37 & 42 & 44 & 38 & 34 & 40 & 40 \\
$\mathrm{Mo}$ & 11 & 20 & 6 & 9 & 6 & 8 & 6 & 9 & 9 \\
$\mathrm{Ni}$ & 98 & 109 & 121 & 93 & 74 & 104 & 99 & 102 & 102 \\
$\mathrm{~V}$ & 231 & 240 & 277 & 198 & 135 & 146 & 147 & 123 & 123 \\
$\mathrm{Zn}$ & 203 & 194 & 179 & 144 & 123 & 204 & 271 & 519 & 519 \\
$\mathrm{Cd}$ & 1 & 1 & 1 & 1 & 0 & 1 & 1 & 2 & 2 \\
$\mathrm{Hg}$ & 1 & 1 & 1 & 1 & 1 & 1 & 1 & 1 & 1 \\
\hline
\end{tabular}

Table 2. Leached fraction in $\mathrm{mg} / \mathrm{kg}$ (ppm by weight) figured as elements in $\mathrm{mg}$ divided by dry weight of total in kilograms. Liquid to solid rate is $10 \mathrm{ml} / \mathrm{g}$. Method used is SS-EN 12457-3. All values are below statutory limits, cf text. Statutory limits according to the acceptance criteria for disposal at a landfill for non-hazardous waste is also shown for comparison.

\begin{tabular}{ccccccccccc}
\hline $\begin{array}{c}\text { Ele- } \\
\text { ment }\end{array}$ & $0-1 \mathrm{~m}$ & $2-3 \mathrm{~m}$ & $4-5 \mathrm{~m}$ & $6-7 \mathrm{~m}$ & $8-9 \mathrm{~m}$ & $\begin{array}{c}11-12 \\
\mathrm{~m}\end{array}$ & $\begin{array}{c}13-14 \\
\mathrm{~m}\end{array}$ & $\begin{array}{c}15-16 \\
\mathrm{~m}\end{array}$ & $\begin{array}{c}16-17 \\
\mathrm{~m}\end{array}$ & $\begin{array}{c}\text { Legal } \\
\text { limit }\end{array}$ \\
\hline $\mathrm{As}$ & 0,01 & 0,02 & 0,03 & 0,03 & 0,05 & 0,03 & 0,07 & 0,05 & 0,06 & 2 \\
$\mathrm{Ba}$ & 0,51 & 0,65 & 0,67 & 0,89 & 0,59 & 0,55 & 0,60 & 0,38 & 1,08 & 100 \\
$\mathrm{Cd}$ & 0,00 & 0,00 & 0,00 & 0,00 & 0,00 & 0,00 & 0,00 & 0,00 & 0,00 & 1 \\
$\mathrm{Cr}$ & 0,02 & 0,07 & 0,05 & 0,02 & 0,01 & 0,03 & 0,01 & 0,01 & 0,01 & 10 \\
$\mathrm{Cu}$ & 0,03 & 0,02 & 0,01 & 0,01 & 0,01 & 0,01 & 0,01 & 0,02 & 0,34 & 50 \\
$\mathrm{Hg}$ & 0,00 & 0,00 & 0,00 & 0,00 & 0,00 & 0,00 & 0,00 & 0,00 & 0,00 & 0,2 \\
$\mathrm{Ni}$ & 0,02 & 0,01 & 0,01 & 0,01 & 0,01 & 0,01 & 0,01 & 0,01 & 0,07 & 10 \\
$\mathrm{~Pb}$ & 0,00 & 0,00 & 0,00 & 0,00 & 0,00 & 0,00 & 0,00 & 0,00 & 0,00 & 10 \\
$\mathrm{Zn}$ & 0,01 & 0,02 & 0,01 & 0,01 & 0,01 & 0,01 & 0,01 & 0,02 & 0,01 & 50 \\
\hline
\end{tabular}

\section{CHEMICAL PROCESSES INFLUENCING THE PROPERTIES}

The various investigations carried out showed very clearly that the ash in the store had undergone comprehensive metamorphosis. $\mathrm{E} g$ the initial $\mathrm{pH}$ in leach water of fresh or young ash is usually around 12 indicating the presence of Portlandite (calcium hydroxide). In most cases the old ash samples had leach water $\mathrm{pH}$ less than 10 , thus indicating a consumption of the calcium hydroxide.

A large number of sources have been consulted for the compilation presented below, and the references cited comprise only a selection. Partitioning during incineration is dealt with in references $[4,6-12]$. General references on maturation processes under ambient conditions are [13-23].

Ash is not a uniform product that exits a furnace in a constant form. The properties vary sometimes drastically - with e $\mathrm{g}$ fuel composition, type of furnace (fluidised bed or mass 
burn) port of exit and mode of operation. Any utilization of ash will thus have to include a strategy for management of variations in the initial properties.

A furnace functions as a fractional condenser with regard to formation of fly ash. Thus, the most volatile species will condense at the lowest temperatures, e $\mathrm{g}$ zinc and lead chlorides, and the least volatile, e g oxides of calcium, aluminium, silicon and iron, which will (if volatilized at all) condense at the highest temperatures. In addition to the actual ash, combustion residues also include flue gas purification products. These typically contain mainly chloride, sulphate and calcium. Generally, the material is in a highly active chemical form with respect to low temperature water based systems.

Many of the chlorides and also oxides form hydrates immediately when fresh ash is contacted with water. This includes chlorides of lead, zinc and calcium. In this way, initially formed readily water soluble salts rapidly convert to sparingly soluble, non-mobile forms. High valence elements like arsenic, bismuth, vanadium and chromium may form anions under oxidizing conditions. At normal $\mathrm{pH}$-values, hydration processes are slow for oxides of aluminium and silicon. In ash, however, due to the hydration of calcium oxide and the consequent high $\mathrm{pH}$, even these oxides hydrate and dissolve appreciably ([20], on solubilities as a function of $\mathrm{pH}$ ). Thus, good prerequisites are created for secondary reactions in the ash.

As a result of hydration and the associated reactivity, secondary reactions take place in the ash. Considerably more research has been carried out on ash from incineration as compared to combustion of wood-based recycled fuels. Judging from the respective compositions, it is assessed that the secondary reaction products are relatively similar. Examples of phases identified [24] are compiled in Table 3. In addition to the crystalline phases listed in the table, appreciable amounts of non-crystalline glass containing $\mathrm{Si}, \mathrm{Na}, \mathrm{Ca}, \mathrm{Al}$ and $\mathrm{Fe}$ is formed. Further types of reactions include formation of clay, carbonate and sulphide. For the most part such phases are more favourable than those formed earlier during the metamorphosis. It is therefore not optimistic (at least not in general) to exclude such phase from further consideration for the purpose of environmental qualification.

Table 3. Minerals phases identified in incinerator ash after ageing [24']. Less abundant phases are labelled with italic fonts.

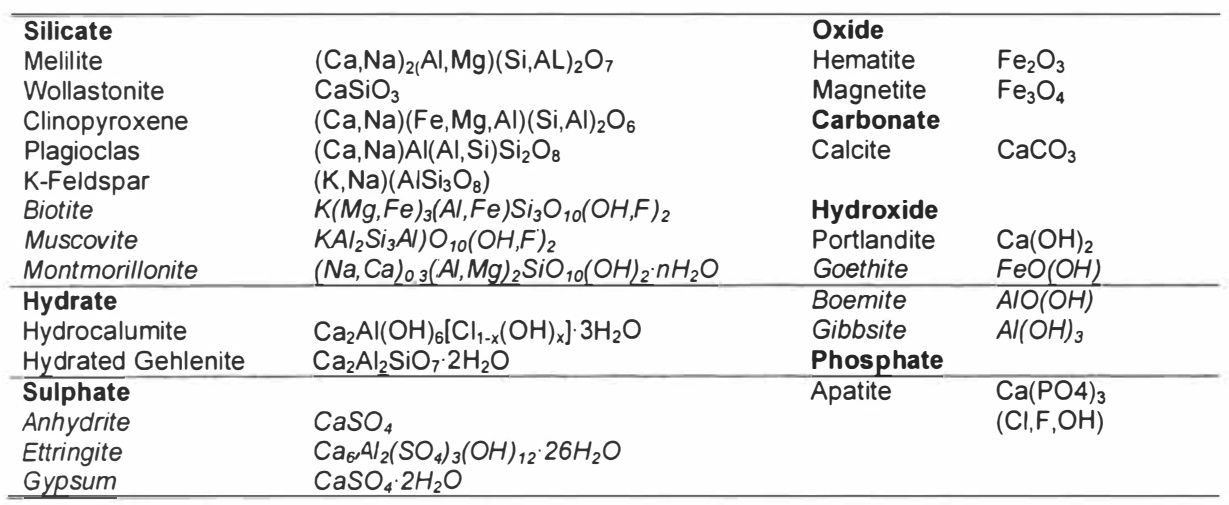


Table 4. Reference substances for selected metallic elements in ash.

\begin{tabular}{|c|c|}
\hline Reference substance & Comment \\
\hline antimony(III)oxide & $\begin{array}{l}\text { Valence usually III but V plausible at high pH values. III is selected } \\
\text { because it is the most pessimistic choice. }\end{array}$ \\
\hline arsenic(III)oxide & $\begin{array}{l}\text { Valence usually III put V plausible at high pH values. III is selected } \\
\text { because it is most pessimistic. }\end{array}$ \\
\hline barium(II)oxide & $\begin{array}{l}\text { Usually barium appears as sulphate. When level of sulphate is } \\
\text { insufficient for this, hydroxide may form. It is selected because it is } \\
\text { the most pessimistic choice. }\end{array}$ \\
\hline lead(II)oxide & $\begin{array}{l}\text { Lead oxide as well as chloride may form initially but lead oxide is } \\
\text { formed after contact with water. Sulphate and carbonate are other } \\
\text { reasonable forms but they have the same classification as lead oxide. } \\
\text { Other lead compounds may form but are expected to be less soluble. }\end{array}$ \\
\hline cadmium oxide & $\begin{array}{l}\text { Initially formed cadmium chloride hydrolyses after contact with } \\
\text { water. }\end{array}$ \\
\hline cobalt(II,III)oxide & According to [14] \\
\hline copper(II)oxide & According to [14] \\
\hline $\begin{array}{l}50 / 50 \mathrm{Cr}(\mathrm{VI}) / \mathrm{Cr}(\mathrm{III}) \\
\text { oxides }\end{array}$ & Special analysis, $c f$ text. \\
\hline chromium(III)oxide & Special analysis, $c f$ text. \\
\hline mercury(II)chloride & $\begin{array}{l}\text { All ashes are low in mercury. Chemistry complex. Chloride form } \\
\text { most pessimistic. }\end{array}$ \\
\hline lantanum(III)oxide & According to [14] \\
\hline nickel(II)oxide & According to [14] \\
\hline vanadium(V)oxide & According to [14] and the most pessimistic form \\
\hline zinc(II)oxide & $\begin{array}{l}\text { Zinc oxide as well as chloride may form initially but oxide form is } \\
\text { formed after contact with water. }\end{array}$ \\
\hline
\end{tabular}

Table 5. Compilation and calculation of total hazard for samples from drill hole $\mathrm{A}$, in $\mathrm{mg} / \mathrm{kg}$ (p.pm by weight) figured as reference substances for the classification and for the hazard in question. All values are below statutory limits. Property in italics indicates that the highest value is to be used (otherwise it is the sum).

\begin{tabular}{lcccccccccc}
\hline $\begin{array}{l}\text { Type of } \\
\text { hazard }\end{array}$ & $0-1 \mathrm{~m}$ & $2-3 \mathrm{~m}$ & $4-5 \mathrm{~m}$ & $6-7 \mathrm{~m}$ & $8-9 \mathrm{~m}$ & $\begin{array}{c}11-12 \\
\mathrm{~m}\end{array}$ & $\begin{array}{c}13-14 \\
\mathrm{~m}\end{array}$ & $\begin{array}{c}15-16 \\
\mathrm{~m}\end{array}$ & $\begin{array}{c}16-17 \\
\mathrm{~m}\end{array}$ & $\begin{array}{c}\text { Upper } \\
\text { limit }\end{array}$ \\
\hline Highly toxic & 0,00 & 0,00 & 0,00 & 0,00 & 0,00 & 0,00 & 0,00 & 0,00 & 0,00 & 0,1 \\
\hline Toxic & 0,05 & 0,06 & 0,06 & 0,04 & 0,03 & 0,04 & 0,04 & 0,03 & 0,03 & 3 \\
\hline Harmful & 0,19 & 0,23 & 0,21 & 0,21 & 0,15 & 0,18 & 0,19 & 0,17 & 0,15 & 25 \\
\hline Corrosive & 0,00 & 0,00 & 0,00 & 0,00 & 0,00 & 0,00 & 0,00 & 0,00 & 0,00 & 1 \\
\hline Corrosive & 0,00 & 0,00 & 0,00 & 0,00 & 0,00 & 0,00 & 0,00 & 0,00 & 0,00 & 5 \\
\hline Irritant & 0,00 & 0,00 & 0,00 & 0,00 & 0,00 & 0,00 & 0,00 & 0,00 & 0,00 & 10 \\
\hline Irritant & 0,05 & 0,05 & 0,05 & 0,04 & 0,03 & 0,03 & 0,03 & 0,03 & 0,03 & 20 \\
\hline Carcinogenic & 0,01 & 0,01 & 0,02 & 0,01 & 0,01 & 0,01 & 0,01 & 0,01 & 0,01 & 0,1 \\
\hline Carcinogenic & 0,00 & 0,00 & 0,00 & 0,00 & 0,00 & 0,00 & 0,00 & 0,00 & 0,00 & 1 \\
\hline Toxic frepr & 0,01 & 0,01 & 0,01 & 0,01 & 0,01 & 0,01 & 0,01 & 0,01 & 0,01 & 0,5 \\
\hline Toxic frepr & 0,04 & 0,04 & 0,05 & 0,04 & 0,02 & 0,03 & 0,03 & 0,02 & 0,02 & 5 \\
\hline Mutagenic & 0,00 & 0,00 & 0,00 & 0,00 & 0,00 & 0,00 & 0,00 & 0,00 & 0,00 & 0,1 \\
\hline Mutagenic & 0,04 & 0,04 & 0,05 & 0,04 & 0,02 & 0,03 & 0,03 & 0,02 & 0,02 & 1 \\
\hline Highly toxic & 0,00 & 0,00 & 0,00 & 0,00 & 0,00 & 0,00 & 0,00 & 0,00 & 0,00 & 0,1 \\
\hline
\end{tabular}




\section{CLASSIFICATION OF THE ASH AND CONCLUSIONS}

Examples of reference substances for classification of waste are listed in Table 4. They were selected based on the chemistry in question in combination with what compounds may be found in the data bases for hazardous substances. In some cases of low presence, worst case assumption was used for simplicity. For chromium either an extremely pessimistic value for chromium-VI is used $(50 \%)$ or an evaluation of available chromium as chromium-VI is made based on leach data.

It is assumed throughout that the ash has been contacted with water and that the rapid hydrolysis reactions have taken place. Worst case is assumed with regard to development over time. Thus, an assessment should cover the time span from initial moistening (which is usually carried out, e g to avoid dusting) and onwards.

The reference substances in Table 4 can be used together with the chemical composition provided in Table 1 to calculate the hazardousness according to [1], and the result is shown in Table 5. All samples were identified as non-hazardous with regard to metallic elements.

Ecotoxic properties are not included in Table 5 since there are no legal limits. However, a comparison can be made with the regulations for labelling of chemical products. These rules are always stricter than those for quantified criteria in the Ordinance of waste. Therefore, the rules for labelling with regard to ecotoxicity are used and this gives rise to a summary "requirement" of $2,5 \%$.

The conclusion of the paper is that there exists methodology by means of which classification according to the Ordinance of waste[1] can be carried out in a conservative but feasible manner. Such a classification, together with an assessment according to the acceptance criteria[2], is necessary before any decision is to be made on how to use or deposit ash from combustion and incineration.

\section{REFERENCES}

[1] Ordinance of waste (Avfallsförordningen). Swedish Government SFS $2001 \mathrm{el} 063$. It harmonizes with the European Union Council Directive 91/689/EEC of 12 December 1991 on hazardous waste.

[2] Ordinance on deposition, criteria and procedures for the acceptance of waste at landfills (Naturvårdsverkets föreskrifter om deponering, kriterier och förfaranden för mottagning av avfall vid anläggningar för deponering av avfall). Swedish Environmental Protection Agency NFS 2004:10.

[3] Svensson, M., Sjöblom, R., Herrmann, I., Ecke H., 2005. Selective mobilization of critical elements in incineration ashes. Värmeforsk Report Q4-140 (in Swedish).

[4] Adler P., Haglund J-E,. Sjöblom R., 2004. Guidance for classification of incineration residues according to the Ordinance of waste. Värmeforsk Report 866.

[5] Brundin, H., Kihl A., Lagerkvist, A., Pusch, R., Rihm, T., Sjöblom, R. Tham, G., 2001e Long term properties of seals containing bentonite. RVF Report 01:12. Svenska Renhållningsverksföreningen (in Swedish).

[6] Abanades, S., Flamant, G., Gagnepain, B., Gauthier, D., 2002. Fate of heavy metals during municipal waste incineration. Waste Management \& Research 2002:20, 55-68. 
[7] Baxter, L. L. et al, 1998. The behaviour of inorganic material in biomass-fired power boilers: field and laboratory experiences. Fuel Processing Technology 54, Nos 1-3, March 1998, 47-78.

[8] Bozkurt, S., Moreno, L., Neretnieks, I., 2000. Long-term processes in waste deposits. The Science of the Total Environment 250 101-121.

[9] Chandler, A. J., Eighmy, T. T., Hartlén, J., Hjelmar, O., Kosson, D. S., Sawell, S. E., Van der Sloot, H. A., Vehlow, J., 1997. Municipal solid waste incinerator residues. Elsevier Science B.V. ISBN 0-444-82563-0.

[10] Obernberger, I., Pölt P. und Panholzer F., 1994. Characterization of wood-based ash from biomass district heating plants. In: On chemical analysis of the ash fractions, environmental impact and research on hazardous substances. Umweltwissenschaften und Schadstoff-Forschung. v. 6(6), pp. 319-332 (in German).

[11] Sjöblom, R., 2001. Hypotheses and mechanisms for formation of deposits containing zinc and lead in conjunction with combustion of recycled wood-based fuels. Värmeforsk Report 734. Miljö- och förbränningsteknik (in Swedish).

[12] Steenari ,B-M., 1998. Chemical Properties of FBC Ashes. Chalmers University of Technology, Doctoral Thesis. Department of Environmental Inorganic Chemistry. ISBN 91-7197-618-3.

[13] Faure, G., 1998. Principles and applications of geochemistry. The 2nd edition. Prentice Hall. ISBN 0-02-336450-5e

[14] Hägg, G., 1966. General and inorganic chemistry. Alqvist och Wiksell

[15] Abbas, Z, 1998. Leaching Behaviour of Residues from Municipal Solid Waste Combustion. Göteborg University, Department of Inorganic Chemistry, Report OOK 98:05.

[16] Appelo, C. A., Postma, D., 1999. Geochemistry, groundwater and pollution. A.A. Balkema / Rotterdam / Brookfield, ISBN 9054101059.

[17] Henderson P., 1982. Inorganic Geochemistry. Pergamon Press. ISBN 0-08-020448-1.

[18] Johnsson, C. A., Kersten, M., Ziegler, F., Moor, H. C., 1966. Leaching behaviour and solubility - controlling solid phases of heavy metals in municipal solid waste incinerator ash. Waste Management 16, Nos 1-3, 129-134.

[19] Lindsay, W. L., 2001. Chemical equilibria in soils. John Wiley \& Sons, Inc., ISBN 1 930665el 1-3.

[20] Mitchell, J. K., 1993. Fundamentals of soil behaviour, 2nd edition. John Wiley \& Sons, Inc., ISBN 0-471-85640-1.

[21] Siegel, F. R., 2002. Environmental geochemistry of potentially toxic metals. Springer Verlag. ISBN 3-540-42030-4.

[22] Speiser, C., 2001. Exothermal reactions in residuals from municipal incinerator waste. Mineralogical and geochemical characterization. Materials and heat balances. Doctoral thesis. Institut für Wasserchemie und Chemische Balneologie, Lehrstuhl für Hydrogeologie, Hydrochemie und Umweldsanalytik der Technischen Universität München. (in German).

[23] Zhu, C., Anderson, G., 2002. Environmental applications of geochemical modelling. Cambridge University Press, ISBN 052180907 X.

[24] Delville, N., 2003. Study of mineralogy and physical chemistry of residues from incineration of domestic waste with regard to utilization of a rotating furnace. Doctoral thesis. École doctorale des sciences fondamentales No 375, Université Blaise Pascal. (in French). 